\title{
Devotional fitness
}

\section{Aspects of a contemporary religious system}

\section{Introduction}

Since the earliest records of religious life, fasting and disciplining the body have been known in most, if not all religious traditions (Griffith 2004: 23). In recent decades, a new form of religiously shaped body imags has emerged in US evangelicalism. Today, there is a lively field of religiously motivated fitness in the USA. There are countless groups, movements, programmes and individuals promoting some kind of devotional fitness. ${ }^{1}$

The aim of this paper is to describe some more or less representative groups within the area of devotional fitness in the USA, to compare their ideas to those held in Christian congregations in Germany and to extract some of the most important features of these movements. ${ }^{2}$ The approach is mainly descriptive; occasionally, however, there will be some analytic or even explanatory fragments, mostly in sections 'Historical fragments' and 'Analytical reflections'.

The descriptive section, 'Examples of fitness in US evangelicalism', will have a short look at three of these movements and then examine one of them more thoroughly, namely, the concept of 'Shaped by Faith' by Theresa Rowe. This programme is a spiritually refined fitness regimen aimed at physical and mental health and well-being. It deliberately blurs the boundaries between different and sometimes opposed areas of knowledge and makes use of 'secular' as well as 'religious' motifs and practices. ${ }^{3}$ As do most programmes in this

1 To get a first impression, have a look at www.spiritandmuscle.com, www.exercisewithpurpose.net, www.danielplan.com, http://www.christianfitnesstv. com/, www.thepowerteam.com, www.weighdown.com.

2 In this paper, I will not in detail focus on economic and marketing related questions, the programmes' connections to congregations and denominations, and gender aspects. However, these questions have to be kept in mind and will be dealt with another time.

3 The term 'secular' will be used quite often here, but-for lack of space-I will not discuss the various definitions of 'secularity' and 'secularisation. For the purpose of this 
area, Rowe continuously reminds her adherents to never stop working with and on themselves, the most important goal of their efforts being the union of mind, body and spirit, in short 'whole-person wellness' (Rowe 20104).

The next part of the descriptive section ('Aspects of religion and fitness in Germany') will look into the connections between sports and religion in Christian congregations in Germany. Evidently, those groups have noticed the attractiveness of sports and fitness in contemporary Western society and consequently have developed their own point of view concerning these issues. Despite some striking similarities with regard to recurring motifs, however, there is no evidence that anything like devotional fitness is about to emerge in the German context.

In the third section, I will briefly describe some of the historical trajectories which have influenced contemporary body ideals in both 'religious' and 'secular' contexts in the United States and Germany. This section has a rather provisional and tentative character-it only serves to hint at some important threads which cannot be elaborated in detail for the time being. To give a historical explanation of devotional fitness is not the goal of this paper.

In the analytical section, I will look at the material again, this time screening it for striking similarities and recurring motifs which allow me to suggest a preliminary definition of 'devotional fitness'. One particular feature of these currents, the blurring of genres, will be dealt with more thoroughly in section 'The blurring of genres in devotional fitness'.

I will end with some ideas as to how these concepts of devotional fitness could be researched within the analytical frame of cultural semiotics (section 'Conclusions'). The paper thus takes up one thread of the envisaged $\mathrm{PhD}$ project, 5 the task of which is to describe devotional fitness as a particular type of popular religion (following Hubert Knoblauch) and to ask whether it may be explained in terms of different theories of society, one of these being the theory of cultural semiotics.

paper, it will suffice to apply a commonsense definition of 'secular' as 'non-religious' (whatever that is). One should be careful, though, not to implicitly uphold the secularisation thesis in a strict manner by using these categories.

4 http://www.shapedbyfaith.com/theresa-rowe-heart-story

5 Working title 'Devotional Fitness: an American Phenomenon of Popular Religion and Analytical Approaches from the Perspective of Theories of Society' ('Devotionale Fitness. Ein amerikanisches Phänomen populärer Religion und gesellschaftstheoretische Erklärungsansätze'). 


\section{Description: what is devotional fitness?}

\section{Examples of fitness in US evangelicalism}

\section{Christian Fitness}

Christian Fitness is a television programme described by its producers as a 'unique, fun and interactive program unlike any other show on television' (Christian Fitness TV 2010 6 ). It combines both nutritional advice, guided fitness exercises and 'uplifting scripture' in 25 differently themed shows. Each programme lasts 30 minutes and is designed for beginners and advanced participants who would like to work-out at home. Christian Fitness is produced by CTN, the Christian Television Network, 7 and can be watched at various times throughout the US on about 20 channels. It is also available on the internet via streaming (Christian Fitness TV 2010 ${ }^{8}$ ).

Christian Fitness has been established because, as its initiators say, they wanted to do something about the negative effects of our sedentary lifestyle. Naturally, this is not just a problem of society in general, but of Christian society as well. As every Christian is called to witness the gospel, they 'must be spiritually and physically strong. Christian Fitness TV therefore regards itself as providing a service to Christians who understand the necessity of a 'spiritually strong life and healthier lifestyle' (Christian Fitness TV 20109).

Chrstian Fitness is not intended to be a sheer fitness programme, designed to heal people physically. More importantly, it is their explicitly stated intention to reach for spiritual salvation. Besides fitness related advice, you will find all sorts of evangelically shaped spiritual advice: to read the Bible, to pray every day, to be baptized and to serve with other Christians in a congregation, to consider the Bible as the final authority and to spread the Christian faith (Christian Fitness TV 2010 ${ }^{10}$ ).

The programme is presented by Robert and Lori Evans. Robert Evans is the liaison to the president of CTN and a personal trainer by profession. He is said to have been called by God to launch Christian Fitness TV:

6 http://www.christianfitnesstv.com/about.html

7 The Christian Television Network has been on air since 1979 and reaches about 15 million viewers. It is intended to promote Christian values and to spread the Gospel and therefore provides a 'wholesome Christ centered alternative to standard television fare' (Christian Television Network 2010, http://www.ctnonline.com/about-ctn. html).

8 http://www.ctnonline.com/affiliate-stations.html/

9 http://www.christianfitnesstv.com/about.html

$10 \mathrm{http} / / / \mathrm{www}$. christianfitnesstv.com/about.html 
After years of training people in martial arts the Lord is now using those experiences for God's glory to help encourage Christians to exercise and have a desire to take care of their Temple of the Holy Spirit by being physically fit and honoring the Lord with their lives in all things (Christian Fitness TV 2010 $\left.{ }^{11}\right)$.

His spouse and female counterpart on the show, Lori Evans, got involved with Christian Fitness after a series of surgeries and illnesses, during which time she reports to have had a vision telling her to help people understand the necessity of leading a healthy life:

Through God's miraculous healing hand and an encounter with the Lord Jesus, she is now using those experiences to help Christians understand the benefits of proper nutrition and learning the word of God (Christian Fitness TV 2010 12 ).

Besides numerous videos on how to exercise, the web pages of Christian Fitness also provide a blog which contains entries about various topics, ranging from nutritional advice, gift ideas, and announcements on upcoming shows, to spiritual guidance (Christian Fitness TV 2010 ${ }^{13}$ ). Christian Fitness thus provides a 'complete package' for committed Christians who are concerned with issues of physical health and well-being and would like to pursue these matters in an explicitly evangelical setting.

\section{The Power Team}

The Power Team is a group of bodybuilders who perform in churches in order to make people enthusiastic about becoming Christian. Their mission is, in their own words, to

reach people of all ages, who would typically not ever attend an event in a church setting, with the gospel of Jesus Christ. Drawing people from all walks of life together into one setting, through the use of performing visually explosive feats of strength, by incredible athletes, who share the lifechanging message of the cross. (The Power Team 2007. ${ }^{14}$ )

\footnotetext{
11 http://www.christianfitnesstv.com/about.html

$12 \mathrm{http} / / / \mathrm{www} . c h r i s t i a n f i t n e s s t v . c o m / a b o u t . h t m l$

$13 \mathrm{http} / / /$ christianfitnesstv.com/blog.html

$14 \mathrm{http} / / /$ www.thepowerteam.com/vision.html
} 
The members of the group regard themselves as called by God to 'reach the lost'. They say they have proselytized 100,000 people since the late 1990s (The Power Team 2007 ${ }^{15}$ ).

The group was analysed by Sharon Mazer in the 1990 . $^{16}$ Mazer argues that the abilities every one of the members performs on stage have a double function: on the one hand, the exceptional strength is a sign of the bodybuilder's faith in Christ, on the other hand it demonstrates the powers of their God (Mazer 1994: 162). Besides drawing people into the church, they also spread what they consider to be moral values. Their ability to perform feats of strength represents their power of will to resist drugs, alcohol, premarital sex and so forth (p. 164). Their central message is: 'That my body is powerful ...that I can perform as other men cannot is due to God's grace, which I have earned by dedicating myself_-soul and body_to Christ' (p. 169).

The Power Team offers live performances across the United States and around the world. They are booked and paid for by host congregations and perform in civic centres, hotel ballrooms, sports palaces, and on fairgrounds. Once booked, they will give several shows during one week at one place, usually from Wednesday to Sunday. Each show lasts about 90 minutes and ends with an altar call (Mazer 1994: 183). All of these so-called 'crusades' culminate in the service on Sunday morning.

They describe their programme as follows:

The Power Team communicates Biblical truths \& scripture utilizing explosive and stunning feats of strength like: breaking baseball bats like twigs, bending horseshoes \& steel bars, crushing concrete walls, rip phone books like pieces of paper and many other incredible power demonstrations. . Then, a Power Team leader closes with a motivational message and altar call, encouraging the lost in the audience to seek salvation. All the momentum, both in the church \& the community, is focused on encouraging visitors \& new converts to attend the Sunday morning service. (The Power Team 2007. ${ }^{17}$ )

15 http://www.thepowerteam.com/letter.html

16 Mazer wrote her paper in 1994, when The Power Team was still led by its founder John Jacobs who left the team in 2003 to initiate a new strength-based ministry named John Jacobs's Next Generation Power Force (http://en.wikipedia.org/wiki/ John_Jacobs_(Power_Team_Minister), accessed on 31 January 2011). However, much of Mazer's analysis remains valid.

$17 \mathrm{http}: / /$ www.thepowerteam.com/faq.html 


\section{Weigh Down Workshop}

The Weigh Down Workshop, founded by Gwen Shamblin in 1986, is somewhat different to the above-mentioned examples. Shamblin is one of the most successful (and controversial) authors in the field of religious dieting. She does not primarily focus on working-out and living healthily, instead she emphasises the idea of losing weight in a religious manner. In her conception, reducing weight turns out to be an essential step on the spiritual path to salvation. Shamblin does not directly state that God does not like overweight people, but, in the words of Gregor Schrettle, being thin, which has long been a cultural imperative in modern US society, is conceived of as a religious imperative in the Weigh Down Workshop (Schrettle 2006: 11, 13).

Shamblin's theory may be summarised as follows: people are overweight because they mistake their spiritual emptiness for physical hunger. She argues that only God can fill this emptiness everlastingly (Weigh Down Ministries $\left.2010^{18}\right)$. The solution to being overweight is simple and consists of three basic rules:

1. Relearn how to feed the stomach only when it is truly hungry.

2. Relearn how to feed or nourish the longing human soul with a relationship with God.

3. Relearn how to recognize the different 'hunger' urges and not confuse them. (Weigh Down Ministries 2010. ${ }^{19}$ )

One can take part in the Weigh Down Workshop in many ways. The most committed way is to join one of the classes, which take place all over the US, ranging from beginners' classes ('Weigh Down Basics') to advanced courses ('Weigh Down Advanced') in six grades. Additionally, you can purchase books and DVDs which explain Shamblin's programme.

\section{Shaped by Faith}

'Shaped by Faith' is a devotional fitness programme designed by Theresa Rowe. ${ }^{20}$ In many ways, the physical aspects of her fitness programme are

$18 \mathrm{http} / / /$ www.weighdown.com/AboutUs/TheWeighDownApproach.aspx

19 http://www.weighdown.com/AboutUs/TheWeighDownApproach.aspx

20 Interestingly, Rowe grew up in a catholic family (Rowe 2008: $38-9$ ). She does not clearly state her religious affiliation, but she has taught fitness classes at the Owensboro Christian Church, a non-denominational church in Kentucky with evangelical affiliations. 
based on Pilates, which Rowe emphasises as an apt technique to reach 'wholeperson wellness' (Rowe 2008: 135).

Rowe stresses that she is not explicitly dealing with how to lose weight. Although losing weight is a positive side effect of her programme, it is not her primary focus: 'Shaped by Faith is not about losing weight; it is about creating a synergy of physical and spiritual health. I call it, quite simply, whole-person wellness.' (Rowe 2008: 1-2.) 'Whole-person wellness' is defined as 'our spirits and bodies working together to make us healthier, holier, and more able to endure' (p. 3). Drawing from her own experience, she believes that 'neither physical health nor spiritual health can be achieved quite as purely without the fusion of the two' (p. 217).

Why does she connect the spheres of healthy living and being religiously committed to the Christian God at all? She has found that the best motivation to live healthily and thus be physically in good shape, is found in my spirit, my connection with God' (Rowe 2008: 2). Consequently, she urges her readers to merge their spiritual and their fitness journey: '[B]y allowing our spiritual walk to support our physical walk, and by realizing how profoundly our physical growth affects our spiritual growth, we embrace a merging of entities that will lead us closer to whole-person wellness' (p. 2). Not only does religion support fitness, it also works the other way round: fitness has an effect on spiritual attitudes: '[A]s I engage in the constant challenge of maintaining a healthy body, God's spiritual truths take on new, stronger meanings and applications in my life' (pp. 2-3). In this way, the mutual fusion of the entities of fitness and religion becomes complete.

The cover of Shaped by Faith promises the 'ten secrets to strengthening your body and soul'. These 'secrets' are elaborated in ten chapters. Building on the basic premise that all areas of life should be merged together when seeking whole-person wellness, every chapter is organised into five parts: 'Shaped by Life, 'Shaped by Fitness', 'Shaped by God', 'Shaped by Prayer', and 'Theresa's Top Three', the last one serving as a short summary of each part. The chapters-and the core ideas of Rowe's 'secrets'-are summarised on the back cover of the book:

Listen to your body and to God's voice

Breathe deeply to release your emotions and to guide your prayers

Partner with other people-and with God-to bring out your best

Stretch your limbs and your expectations of what is possible Align your spine for proper posture and stand tall in your faith

Transform your life through small, daily changes 
Center your actions with a strong inner core

Balance yourself by embracing the instabilities in your life

Endure challenges through exercise and regular time with God

Rest your body with a Sabbath-spirit

(Rowe 2008: back cover).

I will now give some selected examples, taken from Rowe's book to illustrate her style and her pivotal ideas. Every chapter throughout the book begins with the section 'Listen', which contains a quotation from the Bible. ${ }^{21}$ The idea of this chapter is: 'we must listen to our bodies, and we must respond with great care and love for the temple that God gave us' (Rowe 2008: 9-10). Listening to the body means to be aware of the slightest change and to make the appropriate adjustments if necessary (p. 14). This level of awareness should be implemented into day-to-day life. Then our 'mental, physical and spiritual elements function in concert to achieve whole-person wellness' ( $p$. 15). Listening to God and to our body thus promotes the goal of achieving whole-person wellness.

In the chapter entitled 'Breathe', Rowe suggests that breathing can have spiritual and physical dimensions. This idea is drawn from 1 Thess. 5:16-18 which asks Christians to 'pray continually.'22 Consequently, Rowe considers every breath a prayer: 'I have learned that God moves in and out of us with each breath we take' (Rowe 2008: 41). Correct breathing techniques play an important role in exercise; and as you are consciously breathing while working-out, you might as well pray while exercising (p. 40).

The motif of praying continually is further elaborated in one of Rowe's articles published on her website. In 'Working-Out In His Spirit' she considers how to implement this demand into her daily life. Describing the apostle Paul as the ideal archetype of a dedicated Christian who stood up for his faith in every circumstance, she draws the conclusion that it is her task as a believing Christian to follow his example in every possible way. In order to really pray continually, she therefore focuses her mind on prayer in every situation of life. Consequently, this prayerful attitude must also be kept up when working-out at the gym. Praying continually, then, is 'a practice that we can easily

21 Prov. 4:20-2 (New Living Translation): 'Pay attention, my child, to what I say. Listen carefully. Don't lose sight of my words. Let them penetrate deep within your heart, for they bring life and radiant health to anyone who discovers their meaning.' 1 Thess. 5:16-18 (New International Version): 'Rejoice always, pray continually, give thanks in all circumstances; for this is God's will for you in Christ Jesus.' 
incorporate into all facets of our lives' (Rowe 2010). She gives an example of how she herself implements a prayerful attitude in her fitness classes:

Just last week I had my fitness class jumping rope for 6-minute intervals in between strength training segments. During the first jump rope session I decided to pray out loud, sort of a cadence prayer to demonstrate how each of us can turn our work-out time into a praise and prayer session. (Rowe 2010.23)

In the chapter on 'Endurance', Rowe talks about mental and physical suffering, which is described as a key element for gaining spiritual endurance. As we suffer, we are strengthened because our relationship with Christ gains intensity. And suffering not only builds our spiritual endurance, it becomes the true test of it.' (Rowe 2008: 187.)

As mentioned before, Rowe takes many of her work-out routines from Pilates. And although Pilates has been developed without any explicit religious references, ${ }^{24}$ Rowe does not hesitate to integrate it into her spiritually refined work-out:

When a person combines Pilates and strength training exercises along with healing Scriptures, there is a physical and spiritual healing that takes place in the body that is extraordinary. We can strengthen and heal our bodies when we meditate on things above while exercising in His spirit.

(Rowe 2008: 209.)

Even though Rowe does not leave any doubt that she thinks of a sporting life as the best and healthiest way to live, she brings forward a clear set of priorities. God always comes first in anything she does: 'God comes first, followed by a healthy lifestyle' (Rowe 2008: 146). Although she knows of the addictive qualities work-outs can have, she strongly advises her readers to be aware of the higher power of God: 'Of course, our desire for God always comes first, but once we discover the way exercise makes us feel, the way it improves our lives, we can't get enough' (p. 110). Sports and exercising, she emphasises, should never be done for their own sake; one should remember that every-

23 http://www.shapedbyfaith.com/health-tips-and-articles?id=39

24 Developed in the early twentieth century by Joseph Pilates, the programme originally revolves around six principles: concentration, control, centre, flow, precision and breathing (Pilates \& Miller 2007). 
thing is done for God: 'If you choose to run, do so because it makes you more able to endure life and because God has given you life' (p. 186).

Theresa Rowe teaches fitness classes at the Owensboro Christian Recreation Ministry in Owensboro, Kentucky. The purpose of the Recation Centre is, in their own words, 'to introduce and integrate people into the body of Christ'. In addition to that, the centre aims to provide opportunities for families and friends to get together and socialise. They provide 'fitness, sports and leisure activities in a Christian setting' aiming at people from all ages (Owensboro Christian Church 2008 ${ }^{25}$ ).

\section{Aspects of religion and fitness in Germany Protestantism}

The Baptists of Hanau, a town close to Frankfurt, are an evangelical, ${ }^{26}$ nondenominational congregation within the Union of Evangelical Free Church Congregations in Germany (Bund Evangelisch-Freikirchlicher Gemeinden in Deutschland) with approximately 85,000 members in 600 parishes. This specific parish in Hanau arranged a so-called 'Feriensportarena', a sporting event for children from 9 to 14 on their school holidays, in October 2010. Announced under the heading of diaconia, its purpose is to provide the opportunity to do sports, to be together with friends, to learn about the Baptists' beliefs and simply to have fun. Types of sports offered were soccer, volleyball, handball, basketball and others. The typical day, as described on their homepage, would start with a communal breakfast and some spiritual input, such as meditative or religious thoughts and ideas. They would then spend the day together, mainly occupied with all kinds of games and activities. (BaptistenGemeinde Hanau 2010. ${ }^{27}$ )

The Working Committee Church and Sports of the Evangelical Church in Germany (Arbeitskreis Kirche und Sport der Evangelischen Kirche in Deutschland) was founded in 1964. Its intention is to promote 'Christian life in sports', and to encourage Christians to lead a sporting and healthy life. On their website, they hint at the wholeness of body and soul which should be

25 http://www.owensborochristian.org/\#/rec-center/group-fitness

26 The German 'evangelical' congregations are not 'evangelical' in the same way as their US counterparts. The term 'evangelical' is not synonymous with the German term 'evangelisch'. 'Evangelical' refers to a specific kind of Christian religiosity, which is based on the experience of conversion and tends to pronounce the gospel with a certain degree of fervour (Moxter 2010: 74). The German Evangelicals are usually more moderate in both regards. 
taken into the responsibility of the church. The committee is open to ecumenical work but mainly cooperates with representatives of the parishes and congregations of the Evangelical Church in Germany (Evangelische Kirche in Deutschland 2010). Just like the 'Feriensportarena' in Hanau, this approach does somewhat resemble the activities of the Owensboro Christian Recreation Centre.

The missionary organisation 'Athlete calls Athlete' ('Sportler ruft Sportler', abbreviated SRS) is an evangelical group which 'promotes and accompanies sportspeople based on biblical principles' (Schmidts et al. $2010^{28}$ ). It was established in 1971 by Helmfried Riecker as a sub-group of the missionary organisation 'Missionswerk Neues Leben'. They support people who are committed to sports and advocate a lifestyle which 'honours God and the people. They encourage sportspeople to live a Christian life and to express their Christian convictions within the context of their engagement in sports. The group organises Bible meetings for sportspeople, work-out meetings and special training units; additionally they organise events and seminars on topics related to 'Christians and sports' (Schmidts et al. 2010 29). 'Athlete calls Athlete' is fundamentally based on the Gospel. According to their understanding, God wants companionship with all human beings, explicitly including sportspeople. Therefore, they focus on those people who have a talent for sports. In their day-to-day activities 'Athlete calls Athlete' works together with evangelical churches, free churches, congregations and diaconical organisations (Schmidts et al. $2010^{30}$ ). Apart from encouraging people to live a healthy life under the premises of a Christian world-view, 'Athlete calls Athlete' actively proselytises among sportswomen and sportsmen (Schmidts et al. 2010 ${ }^{31}$ ).

Their attitude towards fitness and exercise can briefly be summarised as follows: doing sports is a motivating and joyful activity which promotes a healthy and happy life, but one should not deprive those athletic achievements and challenges of their essential purpose, which is a life led in God's grace. The unity of body, mind and soul is stressed explicitly-in this aspect, their opinion about fitness does not differ much from Rowe's attitude (Schmidts et al. $2010^{32}$ ).

A more obvious connection to US devotional fitness can also be found on the organisation's websites. To illustrate their goals and activities, they pub-

http://www.srsonline.de/index.php?id=101

29 http://www.srsonline.de/index.php?id=101

30 http://www.srsonline.de/index.php?id=101

31 http://www.srsonline.de/index.php?id=696

32 http://www.srsonline.de/index.php?id=696 
lished an interview with the US national soccer player Tobin Heath (born May 29, 1988). She is a successful soccer player in the United States women's national soccer team and deeply involved in her Christian belief. She says that she thinks of every day as a new day to love and understand Jesus and give him space in her professional and private life. She is quoted as saying:

I am excited about his plans for me, he is the boss; wherever he will lead me, I will go, whatever he asks me to do, I will do (Schmidts et al. 2010). ${ }^{33}$

This connection to US evangelicalism is somewhat superficial and of course does not imply that there is any form of correspondence with regard to the spiritual necessity of conforming to certain body images. But it shows that German Evangelicals are aware of the fact that, in the United States, people who share their beliefs can be role models for them both in the religious and in the athletic regard.

The 'Athlete calls Athlete' Academy (labelled SRSakademie) is a study centre focusing, as they put it, on body, soul and spirit. They are convinced that only by connecting these three aspects can success in sports and private life be achieved. Athletes, they claim, should not just be successful in sports, but also have an exemplary function in their parishes. They ought to bring biblical values into sports and sports into the Christian communities (Schmidts et al. 201034). The academy is closely affiliated with the 'New Life Seminar' ('Neues Leben Seminar'), located in the German Westerwald. The New Life Seminar is an education centre for all Christian denominations. In general, it is a missionary education centere, teaching people to spread the Christian faith. They have specialised in missionary work among sportspeople and thus have designed a course of studies in sports missions, which lasts two years (Missionswerk Neues Leben 2010 35 ). The 'New Life Seminar' and the organisation 'Athlete calls Athlete' cooperate in arranging this course of studies. Elements of their teaching programme are: the principles of sports mission, sports and the Bible, sports and community, and sports science (Missionswerk Neues Leben $2010^{36}$ ).

'Ich bin gespannt auf seine Pläne mit mir, er ist der Chef. Wo immer er mich hinführt, will ich gehen. Was immer er für mich bereit hält, will ich tun.' http://www. srsonline.de/index.php?id=1041\&tx_ttnews[tt_news] $=361 \& \mathrm{cHash}=027 \mathrm{c} 32 \mathrm{f} 6 \mathrm{ao} 8 \mathrm{a} 68$ bo6c5b8oace47do7of

34 http://www.srsonline.de/index.php?id=70o

35 http://www.seminar.neues-leben.de/

36 http://www.seminar.neues-leben.de/index.php?file=4_2_13 


\section{Catholicism}

The following is an example of what a Cistercian monk thinks of sports, in this case, basketball. Phillipp Neri lives in the Cistercian monastery 'Stift Heiligenkreuz' close to Vienna (Austria) and is passionate about basketball. He was interviewed by the magazine YOU! in 2007. In this interview, he expressed the opinion that monks have to do sports for a simple reason: monks, just like most people in Western societies, lead a sedentary lifestyle, which lacks balance. Doing sports is just as healthy for monks as it is for every other human being. Consequently, he reports that they have a gym in their monastery and that many of his fellow monks jog in the forest. Asked whether monks do not pray all the time, he says: 'You can consider sports as prayer, too' (Lapka 2007). ${ }^{37}$ This statement strikingly shows that the motif of praying continually and under all circumstances is well known both in Rowe's and in Neri's world-views, although they are set in quite different religious contexts and histories. Neri then elaborates that there are parallels between sports and religion. In his opinion, you can train your team skills in sports and you need those skills in religious life too (Lapka $2007^{38}$ ).

The Catholic sports association 'DJK Sportverband' classifies sports under the heading of 'sports for the people', that is, within the context of diaconia. The organisation is a union of local sports clubs; their intention is to promote the experience of companionship and community, to bring people and cultures closer together, and to harness sports as a nurturing tool in daily life. Sports and doing sports is appreciated as an opportunity to spread Christian values and beliefs (DJK-Sportverband 201039). Thus, taking care of sports education is again considered to be a diaconical activity, as has already been shown with reference to evangelical groups in Germany.

The DJK, founded in the 1920s, has approximately 500,000 members and is one of the largest Catholic organisations in Germany. It is organised in more than 1,100 local groups and 27 unions (Hofschlaeger 2006: 17). They explicitly think of their task as a service to people ('Dienst am Menschen') and draw this conviction from the Gospel (Siemes 2006: 5-6). One of their slogans is that the church and sports are both supposed to serve people. Sports details/44-reportagen/343-drei-punkte-wurf (no longer available online).

38 http://www.youmagazin.com/page/show_details/44-reportagen/343-drei-punktewurf (no longer available online). 
clubs and parishes are expected to be partners in refining communal relationships (DJK-Sportverband $2010^{40}$ ).

The DJK arranges sporting spiritual exercises ('Sportexerzitien'). Spiritual exercises in general are meant to be exercises of spiritual consciousness in stillness and loneliness. Their goal is to think anew about one's faith and to gather strength for life in spiritual contemplation (Keilmann-Stadler 2006: 11). Sporting spiritual exercises are based on the idea that working-out can be oriented on the Christian value of charity (Hofschlaeger 2006: 15). Sports thus becomes a means to an end; the end being a Christian life. Sporting spiritual exercises want to promote a holistic understanding of body, spirit and soul (Keilmann-Stadler 2006: 12). This motif of holism has so far been recognised as an essential feature of both Evangelical and Catholic concepts dealing with sports and fitness in the USA and in Germany.

Differing from US devotional fitness, these sporting spiritual exercises simply provide the chance to find relaxation and concentration in a focused form of companionship (Keilmann-Stadler 2006: 12). Sports and prayer coexist, but they do not necessarily blend together and become one. Frequently, announcements about sporting spiritual exercises reproduce an aphorism attributed to Teresa of Ávila in which she advises to 'be friendly to your body, so your soul will want to live in it'41 (Keilmann-Stadler 2006: 12; Siemes 2006: 5).

Doing sports is considered to be a secular activity which can be used for the purpose of the church. Bernward Siemes ${ }^{42}$ therefore writes that the 'seemingly worldly occupation' of working-out will educate participants in Christian values ${ }^{43}$ (Siemes 2006: 6). Athletic activities can be a means to reach spiritual aims because every sportsman and sportswoman can realise that their breath is an 'elixir of life and a gift from God'.44 You will feel your body more intensely with all senses; sports thus becomes a means on the way to being a spiritually refined human being (Siemes 2006: 6-7). These ideas are strikingly reminiscent of Rowe's concept of breathing and praying.

40 http://www.djk.de/4_kirche_u_sport/frame_kirche_u_sport.htm

41 'Sei freundlich zu deinem Leib, damit deine Seele Lust hat darin zu wohnen.'

42 Bernward Siemes is a Catholic theologian and sportsman working with adolescents in a Catholic community in Bonn, Germany.

43 'Das scheinbar weltliche Tun in sportlichen Vollzügen schult die Teilnehmenden im fairen und achtsamen Umgang miteinander.'

44 'Zum Sport gehört die Atemschule: beim Laufen, Schwimmen den richtigen Atemrhythmus finden, bei der Ausdauer den Atemtakt halten. . .Den Atem als Lebenselixier und Geschenk Gottes wahrnehmen. Nicht umsonst wird der Geist Gottes auch als Ruach = Atem Gottes bezeichnet!' 
Ultimately, Siemes emphasises that sporting activities are considered useful in a transcendent context: movement, he writes, as the source of life, can have effects on spiritual attitudes and abilities. It can spawn spiritual experiences and trigger one's journey towards God (Siemes 2006: 8). These ideas do not yet explicitly build on a slimness ideal; neither do they proclaim that spiritual salvation can mainly be reached through physical exercise, but they rely on the same basic understanding which is brought forward by Rowe.

\section{Historical fragments: predecessors and prerequisites}

\section{'Religious' and 'secular' body ideals in North America}

It is at around 1900 that most scholars place the roots of modern American fitness history (Griffith 2004: 70; Schrettle 2006: 151). But only in the period after the Second World War, Christians from many denominations developed ideas of health and thinness, inextricably blending 'secular' and 'religious' motivations (Griffith 2004: 3, 17). These turned out to be highly appealing to a lot of adherents reaching far into the twenty-first century (Griffith 2004: 160).

However, these ideas can be traced further back into the history of US culture. Being thin and living healthily is neither a new value, nor is it an exclusively religious one. On the contrary, it seems evident and even commonsense that the ideas of slimness and beauty which are brought forward by trends in US devotional fitness are deeply entrenched in non-religious areas of society. Nevertheless, it can be argued that they developed out of religious (mostly evangelical) ideas: '[R]eligion has played a key role in the development of the American thinness mania in some unusual and complex ways' (Schrettle 2006: 92). With regard to the religious history of America, Protestantism has played a major part in shaping religious and secular body images since colonial times (Griffith 2004: 4). ${ }^{45}$ In fact, dieting is an essential element of US modern body images, but I will not follow this thread here. Emerging in the nineteenth century, New Thought combined Swedenborgianism, Mesmerism, spiritualism, holiness-movement, evangelicalism, and, most importantly, mind-cure. It attributed great potential to the powers of the human mind, which was thought to be able to overcome bodily needs. Refraining from human appetites thus became an important part of New Thought practices and physical signs of successful abstinence-such as slenderness-were appreciated. (Griffith 2004: 97; see Griffith 2004: $110 \mathrm{ff}$. for more details.) 
popular culture-a culture strongly influenced and shaped by religion, that is, the variations of US Protestantism. Consequently, Schrettle argues that 'a decisive reason why America is literally obsessed with weight loss is to be found in its religious heritage and tradition' (Schrettle 2006: 94).

Both religious and non-religious historical backgrounds shape the emergence of devotional fitness. However, the connection is complex and mutual. Religion did not simply adopt secular values, but had itself an impact on the emergence of these values. A historical predecessor of the contemporary slimness imperative had first been stated in a religious context, that is, the milieu of the early Puritan settlers in the USA. They were confident that they were God's chosen people, freed from their European 'captivity' and, to uphold the biblical metaphor, guided to a new 'promised land' by God. Although the founding fathers of the US promoted a strict secularism when they established their citizenship, strong Christian components persisted in America's self-understanding (Schrettle 2006: 123-4). Among Christian elements, there were the Puritans' ideas of chosenness, of individual responsibility, and, more importantly, of asceticism, frugality and strict avoidance of all spontaneous enjoyments. Schrettle therefore argues that this Puritan asceticism slowly developed into a secular thinness imperative (p. 125).

The insightful argument Schrettle brings forward builds on the Weberian thesis of the Protestant ethic. This ethic spawned capitalism which gave birth to consumer culture which in turn was the fruitful ground on which the (nonreligious) slimness imperative could grow (Schrettle 2006: 126).

Asceticism. . could not simply be replaced by boundless tolerance for indulgence in consumption. ... American culture was not ready to accept consumerism as a new universally valid approach to life without any counterbalance.... .Dieting was ideally suited to meet these requirements. The attack on fat was apparently perceived as an appropriate means through which the nation felt it could keep up, in modified form, the Puritan tradition and heritage. (Schrettle 2006: 151-2.)

It is arguable to what extent the Puritan heritage has had a decisive impact on today's slimness imperative and whether or not other influences might have played an equally important role. ${ }^{46}$ But undeniably, the non-religious slimthe West and a widely observed fear of the effects of a sedentary and urbanised lifestyle. 
ness imperative may, at least in part, be understood as an indispensable reaction to the economic abundance of the twentieth century, which itself may be traced back to the Protestant ethic and its economic implications.

Bearing these arguments in mind, the situation of the Evangelical congregations in North America in the 1950 s and 6os may be looked at in a different light: religious officials and congregations had to deal with the now widely accepted non-religious slimness imperative. They had several options to deal with this culturally approved body ideal: ignoring it, opposing it, or adopting it. Gwen Shamblin's Weigh Down Workshop, for example, can be seen as a complete adoption of the non-religious slimness imperative (Schrettle 2006: 160). Shamblin does not try to evade the all-encompassing significance of slimness, rather, she turns to the highest authority imaginable to enforce this imperative. 'The complex blend of religious and cultural influences. . . thus creates a uniquely strong compulsion to conform to the prevailing slimness ideal' (p. 166). Just as the Puritans understood wealth and success as signs of God's grace, Shamblin interprets proper body weight as a manifestation of God's approval.

The initial premise that believers are rewarded for their efforts, either through material blessings (for the Puritans) or weight loss (for Shamblin), promptly becomes the basis for the reverse conclusion. Only those who are 'blessed' with either success or beauty are righteous in God's eyes, and salvation is a result of good works or good looks (Schrettle 2006: 185).

The point is that the Weigh Down Workshop is deeply embedded in both religious and secular dimensions of US history and cannot easily be transferred to other cultural systems. Shamblin's ideas draw from a cultural environment which is based on the slimness imperative as a constitutive element of modern American popular culture (Schrettle 2006: 198). What used to be a 'secular' value with 'religious' roots-conforming to a standardised body ideal-has been implemented into the religious framework of certain groups within Evangelical Christianity. 47

\section{Residues of Protestant ethics in European body images}

Given that the religious slimness ideals in devotional fitness are closely linked to body ideals developed in popular culture, the question arises as to

47 Of course, this is only one possible explanation. Devotional fitness might as well be understood as 'westernised yoga' - a thesis which, though highly plausible, has not been considered by Schrettle. I will consider this thesis comprehensively in further research. 
what kind of body standards are brought forward in non-religious sectors of European societies.

And again, the effects of the Protestant ethic understood in Weber's sense are also observable in Europe, though in a somewhat different fashion than in North America. In secular European culture being healthy is a widespread and accepted goal and indulgence is considered an obstacle standing in the way to this goal. Svenja Zimmer argues that the aim of healthiness shows the same irrational qualities that have been observed by Max Weber with regard to the acquisition of monetary wealth. Both the striving for health and the striving for money impose some kind of asceticism on people. While Weber's conception assumed that the inner worldly asceticism of Protestantism was peformed in the hope of eternal life, the goal of inner worldly health-asceticism is intended to render possible a long, albeit not eternal, life on earth. Zimmer therefore states that the transcendent goal is turned into an immanent goal lacking religious connotations. Religious concepts are abandoned in contemporary health-oriented European secular culture. (Zimmer 2010: 37.) In short: the qualities which Weber ascribed to economic wealth can equally be found in society's attitudes towards nutrition, health and ideals of slenderness, but they do not have religious dimensions any more (Zimmer 2010: 54).

Consequently, the European body ideal of our times may be called a 'secular' one. Compared to US devotional fitness, one could therefore assume that in Europe the re-importation of religious qualities into the widespread and mostly accepted slimness ideal has not (yet) taken place, or, stated conversely, that secular body ideals have not yet been fully implemented into Christian world-views. This lack of spiritual input might be explained by the fact that 'religious' and 'secular' realms are and have been explicitly disjointed in most Western European societies. Therefore, a blending of the areas cannot be as easily achieved as in the USA.

Even if there does not seem to be much of a chance for devotional fitness to develop in a genuinely European fashion, one should at least assume that it might be imported from the USA, as are so many other trends. But that does not seem to be the case, either. Why has devotional fitness not yet reached Europe? Books and DVD's can easily be purchased all over the world, but as of today you will not find any such phenomena as German Weigh Down Workshop groups or fitness classes based on Rowe's programme. Once again, this can probably be explained by pointing out the differences between European and US religious history. In the USA, religion has always been closer to popular culture: it has constantly been more visible and has opened up quickly to new media and technologies. These conditions may have facilitated 
the re-importation of religious ideas into seemingly 'secular' fasting, sports and dieting and, vice versa, the inclusion of 'secular' values into Evangelical settings. In Germany, and probably in Europe as a whole, Christian congregations have mostly taken conservative points of view, opposing or even refusing popular culture and the values connected to it.

\section{Analytical reflections}

\section{Genre: pray yourself thin}

The US movements described above can be situated within a genre tentatively called 'Pray yourself thin'. This genre and its developments will be introduced here in a sweeping fashion to embed the above-described movements, especially Rowe's fitness programme, into the general developments within this field.

In 1957, Charlie Shedd, a Presbyterian priest, published Pray Your Weight Away, in which he explicitly stated that one could measure the amount of individual sin by simply stepping on the scales (Griffith 2004: 162). 'Fat was the embodied mark of disobedience and distance from God, while weight reduction signified the restoration of holiness' (p. 165). Belonging to the same genre, Deborah Pierce authored the book I Prayed Myself Slim in 1960. Pierce, an episcopate from the southern states, pronounces body and beauty standards to be God's will for all Americans, marking all deviance from that norm as a $\sin$ (p. 162).

Both Shed and Pierce drew on New Thought ideas, ${ }^{48}$ which had by then become acceptable within the Protestant society (Griffith 2004: 163). Even in these early examples of the genre, Ruth Marie Griffith spots an interconnectedness between popular and devotional culture:

[T] hese Christian slimming programs were attractive because of their practical aspects, which linked each book to the popular diet literature of the day and so lent it an air of sensibility without subtracting from its devotional message. ... Prayer was the key to a thin body, but more commonplace activities played a no less essential role. (Griffith 2004: 168.)

48 As mentioned above, I cannot deal in depth with the influence of New Thought on devotional fitness in this paper. 
The non-devotional aspect of these programs was their promise of a healthy, happy life with friends and family which was achievable to all if they obeyed a dietary regimen (Griffith 2004: 170).

As hinted at in the introduction, the genre is abundant with ever-new books, groups, authors and work-out programmes appearing on the scene. Only a few of them have been taken into consideration in section 'Examples of fitness in US evangelicalism' here, and those will serve as a frame of reference for the following sections, which try to undertake a systematic approach towards the phenomenon.

\section{Towards a definition of 'devotional fitness'}

Based on the descriptive section, I suggest a preliminary definition of devotional fitness as a symbolic subsystem of religion. The understanding of religion as a symbolic system consisting of subsystems is based on Clifford Geertz's concept of religion as a cultural system. Following Geertz, culture may be understood as a

historically transmitted pattern of meanings embodied in symbols, a system of inherited conceptions expressed in symbolic forms by means of which men communicate, perpetuate, and develop their knowledge about and attitudes toward life (Geertz 2009: 89).

In his often quoted definition, ${ }^{49}$ Geertz notes as one of the five features of religion that it is 'a system of symbols' (Geertz 2009: 90). Symbols, he elaborates, are objects, events or acts which convey meaning. They are the 'tangible formulations of notions, abstractions from experience fixed in perceptible forms' (p. 91). Symbols constitute symbolic systems which serve as models for and of society (pp. 93-4).

49 His full definition says that 'a religion is: (1) a system of symbols which acts to (2) establish powerful, pervasive, and long-lasting moods and motivations in men by (3) formulating conceptions of a general order of existence and (4) clothing these conceptions with such an aura of factuality that (5) the moods and motivations seem uniquely realistic' (Geertz 2009: 90). Geertz's definition as a whole could be a suitable starting point to decide whether or not devotional fitness is religious from the scholarly point of view, but I will deal with this question from a somewhat different angle. 
What characteristics render a symbolic subsystem of religion a system of 'devotional fitness'? Following Robert A. Orsi,50 Griffith writes: 'Devotionalism. . .is "religious experience at the limits", in the sense that prayerful appeals to divine figures are so often suffused with sickness, suffering, fear, and loss; and yet devotional experience materializes in deceptively mundane forms' (Griffith 2004: 5).

One may think that it is just the semantics used by fitness teachers that make their programmes look like religion. '[C]ontemporary diet and fitness jargon is glutted with religious metaphors, conversion narratives, testimonials, and a vocabulary that tirelessly invokes the rubric of "spirituality"' (Griffith 2004: 11). But that is not all there is to observe; religious associations do not just remain on a superficial, metaphorical level:

What marks religious diet culture as devotional is the addition of expressive relationships with sacred figures such as God or Jesus, accompanied by the belief that the human body's fitness affects such relationships in direct and indirect ways. . . . Devotional dieters. . .deeply care about food intake and physical health because they sense that the able-bodied-those who restrain their bodily desires and seek some degree of health-may more easily establish familiar, loving relations with the divine powers controlling the world. (Griffith 2004: 5.)

Much of what marks the contemporary message as distinctive, in fact, is not its concern with food and fitness per se, but the apparent willingness of authors to accept and even celebrate the most extreme cultural body standards, converting them from social constructs into divine decree (Griffith 2004: 204, italics added).

In short: the crucial idea which separates devotional fitness from secular fitness and locates it in a distinctively religious realm is the idea that 'fit bodies ostensibly signify fitter souls' (Griffith 2004: 6), that 'thinness is (or should be) the visible marker of godliness' (p. 180). ${ }^{51}$ available online.

51 Taking a completely different approach, 'secular' sports could of course be analysed from the point of view of a scholar of religion applying a functional definition of religion. Certain elements in non-religious sports can easily be analysed from the perspective of our discipline, such as personal stories of 'conversion'. The crucial dif- 
The participants' motive is not just to lose a few pounds, look better and live more healthily. The real aim of keeping to a regimen is to show obedience to God's will; everything else is just a positive side effect (Griffith 2004: 216). '[B]ecause the body is God's temple, being slender is part of living the true Christian life' (p. 180).

On a general and analytical level, I will consider devotional fitness as a subsystem of the cultural symbolic system of religion as described above. On a more specific and descriptive level, devotional fitness can be depicted as a particular form of popular religion in Hubert Knoblauch's sense. This will be elaborated in the following paragraphs.

The genre of devotional fitness is 'highly individualistic' and based on personal commitment and achievement (Griffith 2004: 171). This trait of character in the emerging phenomenon of devotional fitness hints at a general condition of modern religious movements: they are widely considered to be individualistic and subjectivist, putting the individual and his/her goals at the centre of attention-an understanding which has been comprehensively researched in the social and cultural sciences (e.g. in Kneer \& Nassehi 1993: 162; Dumont 1991: 287-8; Knoblauch 2009: 81-2). This is one of the reasons I would like to think of devotional fitness as a particular form of popular religion in Hubert Knoblauch's sense, which stresses, among other characteristics, the apparent trend of subjectivisation in recent religious movements.

Popular religion, as understood by Knoblauch, highlights two characteristics of contemporary religion: popularity and the transformation of religious communication (Knoblauch 2008: 3). Religious communication crosses the boundaries between institutional settings and popular culture. Signs and symbols interpenetrate and are not just confined to ecclesiastical and institutional settings (p. 4). This blurring of genres takes places on two levels: Firstly, there is a rather superficial exchange of symbols in communication. Secondly, there is also a communicative transfer on a more profound level in terms of themes and topics (p. 5). The third feature of popular religion, which has already been hinted at, is a distinct subjectivisation. Each and everyone may search and find answers to the ultimate questions for him/herself (p. 7). All these traits may easily be recognised within the above described field of devotional fitness: Firstly, devotional fitness takes place in a highly popular current of contemporary fitness culture. Secondly, there is a spirited exchange of

ference, though, is that a secular sportsman would describe his 'conversion' in terms of being overweight and being thin, whilst a religious sportsman would add the aspect of being far from god and being close to god. 
communicative symbols and topics: religiously rooted motifs are observable in devotional fitness and themes from 'secular' mainstream culture are widely spread within the semiotic system of devotional fitness. And thirdly, the individuals themselves are expected to find their own paths to physical and spiritual perfection, choosing from a variety of regimens available on the market.

Finally, it has to be stressed that the area of devotional fitness is indisputably highly heterogeneous. The only common ground is some idea of a healthy (and usually slim) body, which can and should be reached through devotional practice and for the glory of God. The ways to get there are as diverse as the people behind it. The Power Team promotes force and muscle, Rowe puts forward a rather moderate means of evangelically enhanced Pilates, and Shamblin in the end does not recommend exercise at all, because, in her account, working-out physically is, like eating, just a pretext to fill emotional holes:

[T]rust God, not exercise-He is jealous of our misplaced dependence. The only exercise you require is getting down on your knees to pray and getting the muscle of your will to surrender control of your natural, Godgiven hunter and fullness guide to the Creator. (Shamblin, quoted in Schrettle 2006: 132.)

After having defined devotional fitness in a preliminary way, I will hint at some recurring motifs, the crucial symbols which can be observed in the communicative system.

1. The body as God's temple. You can find this idea in Rowe's account: '[W]e must respond with great care and love for the temple that God gave us' (Rowe 2008: 9-10, italics added). Additionally, Rowe teaches a fitness class at Owensboro Christian Church with the intention to 'help you take care of your body (temple of the Holy Spirit) by dedicating each class to God our heavenly Father' (Owensboro Christian Church 2008, italics added ${ }^{52}$ ). You can also find this motif in Christian Fitness TV: '[T] ake care of [the] Temple of the Holy Spirit by being physically fit' (Christian Fitness TV 2010, italics added ${ }^{53}$ ).

2. Continuous prayer. The next central foundation of Rowe's devotional fitness programme is the imperative to pray continually, which is taken from 
1 Thess. 5:16-18.54 Strictly applying this imperative in daily life, it is inevitable to consider working-out just as much as an opportunity to pray as every other activity (Rowe 201055).

3. God as a motivator. The above-mentioned class taught by Rowe is based on the slogan 'I can do all things through Christ who strengthens me' (Phil. 4:13) (Owensboro Christian Church 200856). Christ thus becomes the ultimate motivator and last resort the devotee will turn to in his physical exhaustion. Shamblin makes use of the same source of motivation when she argues why her diet programme differs from non-religious programmes.

4. Suffering builds endurance. Suffering, whether in life or in an extremely exhausting exercise session, builds both physical and spiritual endurance: '[S] uffering not only builds our spiritual endurance, it becomes the true test of it' (Rowe 2008: 187).

5. Breath and the Holy Spirit. This motif is based on Job 33:4. 57 Rowe perceives breathing as a direct connection to God: 'I breathe to live, I breathe to maximize exercise, and I breathe to take in the breath of the Almighty' (Rowe 2008: 23, italics added). Rowe also states: 'I have learned that God moves in and out of us with each breath we take' (Rowe 2008: 41). Especially while doing sports, breathing often becomes a strikingly conscious effort-and thus God's presence will be more intensely part of the exercising. Similar ideas can be found in Catholic sporting spiritual exercise.

6. Holism. As has already been hinted at, holism is a wide-spread idea in both the US and European 'religious' and 'secular' wellness and fitness contexts. In Rowe's understanding, holism is realised in the striving for 'Whole Person Wellness' (Rowe 2010 ${ }^{58}$ ). Moreover, the unity of body, mind and soul is an important featue of both evangelical and Catholic organisations in Germany.

54 'Rejoice always, pray continually, give thanks in all circumstances; for this is God's will for you in Christ Jesus.'

55 http://www.shapedbyfaith.com/health-tips-and-articles?id=39

$56 \mathrm{http}: / /$ www.owensborochristian.org/\#/rec-center/group-fitness

57 Job 33:4 (New International Version): 'The spirit of God has made me; the breath of the Almighty gives me life.'

58 http://www.shapedbyfaith.com/theresa-rowe-heart-story 
7. Attentiveness. The idea of attentiveness is very obvious in Rowe's programme: 'In our wellness journeys, we must listen to how our bodies respond to even the smallest movements. . In fitness, this kind of attentiveness is often called mind-body exercise.' (Rowe 2008: 14.) Being aware of one's body and its needs has also been highlighted as an essential ability in German Catholic groups.

8. Balance. Rowe emphasises the need to strive for balance in both physical and spiritual things (Rowe 2008: 145-6). Closely related to holism, this symbol of a balanced life is a prevalent notion not only in contemporary religious movements but also in alternative holistic approaches to healing.

It will now be interesting to have a closer look at the roots and provenance of these symbols, how they came to be part of the semiotic system of devotional fitness and how they constitute some form of 'identity' for this system. For example, the last three motifs (holism, attentiveness, balance) do not seem to be of exclusively Christian origin; at first glance, and rather intuitively, they are associated with popular forms of Eastern religions in the Western world. These and other questions will not be further elaborated in this paper, but they will be examined comprehensively in follow-up research.

These have been the most important recurring motifs within the symbolic system of devotional fitness. The most striking structural characteristic of this is the blurring of branches. This structural feature is closely linked to the substantial idea of holism; the concept of holism is a necessary prerequisite for a structural blending of entities. This will be dealt with in the next section.

\section{The blurring of genres in devotional fitness}

One of the central characteristics of devotional fitness is the intermingling of secular and religious realms. That this is not merely an observer-imposed fusion will now be shown by drawing from primary sources, mainly from Rowe's book Shaped by Faith.

Rowe's idea of 'whole-person wellness' can only be achieved by blending spiritual and physical concepts: '[B]y allowing our spiritual walk to support our physical walk, and by realizing how profoundly our physical growth affects our spiritual growth, we embrace a merging of entities that will lead us closer to whole-person wellness' (Rowe 2008: 2, italics added). Fitness practice reaches far into spiritual affairs in Rowe's opinion: 


\begin{abstract}
'Shaped by God' will describe how these fitness practices influenced my discovery of God and how my relationship with Him intertwines into my fitness routines. This is where simple fitness actually transcends into whole-person wellness. (Rowe 2008: 4-5, italics added.)
\end{abstract}

In a similarly striking manner, the first question to be answered in the FAQsection of Shamblin's website is: 'What does God have to do with this [weight loss] anyway?' The answer to this question is that only with God's help will the dieter succeed in his quest to resist the temptations of food, to stand firm against the 'magnetic pull of the refrigerator' (Weigh Down Ministries $\left.2010^{59}\right)$.

This convincingly illustrates that even insiders such as Shamblin and Rowe recognise that religion and dieting or religion and fitness are not necessarily perceived as belonging together. They realise that the society they live in does not automatically intertwine spiritual and physical affairs and, therefore, spend a good deal of their efforts on bridging those different areas.

This blurring of genres does take place on several levels. Beyond the general level of religion/fitness, the merging of conceptions of body and spirit as well as of body, spirit and mind, is strongly highlighted. Spirit and body are mutually interconnected; it is not just the body which receives support from the spirit, the same is true the other way round: '[A]s I engage in the constant challenge of maintaining a healthy body, God's spiritual truths take on new, stronger meanings and applications in my life' (Rowe 2008: 2-3). The overlapping is not one-sided-there is a bidirectional penetration of the areas.

The overlapping of pure physical exercise and spiritual growth is sometimes, especially in the context of Rowe's idea of holism, put in terms of simple metaphors like this one: 'Just as aligning our physical spine makes us strong, balanced, and healthy, aligning ourselves with God and putting on His armor strengthens us, protects us, and satisfies our soul' (Rowe 2008: 103). However, Rowe often leaves this level of plain metaphorical speech behind and puts forward a substantial merging of physical fitness and spiritual ability. In the following statement, which has already been referred to above, she manages to incorporate Pilates, which originally lacks religious components, into her system:

When a person combines Pilates and strength training exercises along with healing Scriptures, there is a physical and spiritual healing that takes 
place in the body that is extraordinary. We can strengthen and heal our bodies when we meditate on things above while exercising in His spirit. (Rowe 2008: 209.)

Spiritual and physical health can only be achieved if you pursue both goals together:

I am, after all, asking you to apply not only challenging physical lessons but also spiritual ones. But the trajectory of my own life has made me convinced that neither physical health nor spiritual health can be achieved quite as purely without the fusion of the two. (Rowe 2008: 217, italics added.)

This manner of merging different entities is characteristic of Rowe's programme. The Power Team, for example, reveals dissimilar qualities. They make use of a fusion of popular performance and evangelical proselytising (Mazer 1994: 163). This is a completely different way of merging two originally separate areas: 'What we see is essentially a pastiche that visibly mimics many of the most popular, most secular forms of performance' (p. 166). However, Mazer remarks that this kind of fusion does indeed have effects on a deeper level: 'What began as an echo of popular performance now claims its place as an act of worship' (p. 185). Fitness becomes prayer, just as it does in Rowe's concept.

The intermingling of religious and non-religious areas is also convincingly shown in Schrettle's account of Shamblin's Weigh Down Workshop:

The Weigh Down Workshop, on the one hand, is an organization that assists people in their pursuit of the seemingly secular goal of weight loss, and it employs religious means both to substantiate the necessity of this collective pursuit, and to achieve the desired goal (Schrettle 2006: 107).

As has been shown in the previous sections, the intermingling of religious and non-religious genres is not a new phenomenon in US culture, but has accompanied the emergence of devotional fitness from the start. Griffith stresses the interconnections between secular and religious culture several times. For a long time, scholarly studies have brought forward the assumption that the history of American fitness culture has been a history of secularisation. Griffith's analysis instead 'highlights the indispensable role of religious belief and practice all along the way' (Griffith 2004: 12). 
Because the historical developments of both secular and religious fitness culture and body images are obviously closely linked, Griffith talks of a 'blurring of genres' especially visible in more recent publications in the genre of 'Pray Yourself Thin'. In the course of a professionalisation of devotional fitness guidebooks, authors now mostly abolished the assumption that there was

\begin{abstract}
a Christian culture separate and apart from the secular world: now, identical norms for health and beauty were simply assumed to apply to Christians and heathens alike, and acceptance in the secular world evidently bolstered the credentials of Christian dietitians (Griffith 2004: 186).
\end{abstract}

A blurring of genres is also perceivable with regard to the sources cited in devotional fitness literature. Bible passages and quotes taken from 'scientific' studies alike are constantly used to foster nutritional advice while emphasising that the modern sciences merely confirm biblical truth (Griffith 2004: 205). Finally, there is no clear line to be drawn between religious and secular norms in American fitness culture. Even when people argue that slimness should only be a spiritual goal they still mention the worldly benefits of their convictions such as health, beauty, love and prestige (Griffith 2004: 241).

\title{
Conclusions
}

Looking back at the introduction, the goals of this paper were to describe some groups and concepts within the area of devotional fitness in the United States, to compare those ideas to Christian congregations in Germany and to extract some of the most important features. These tasks have been dealt with in the previous sections. Although more research is under way in this concern momentarily, for now the description provided may serve as a useful basis to conduct further analyses.

Summing up this brief account of devotional fitness, I will return to a tentative hypothesis which can generate subsequent research on this topic: devotional fitness is a religious symbolic subsystem of society which can be analysed in terms of Hubert Knoblauch's concept of popular religion. Devotional fitness may be seen as an area of society which is characterised by the overlapping of demarcations, especially of demarcations dividing the religious from the secular and religious from medical subsystems. Devotional fitness may therefore be seen as an example of what Knoblauch (2009: 266) calls popular re- 
ligion. Knoblauch emphasises the mutual interconnections between popular culture and religious culture in popular religion. The incidences of popular culture in religious settings (e.g. bodybuilding in churches), and the appearances of religious culture in fitness contexts (e.g. Gospel recitations in Pilates work-outs), are so tightly connected that it seems impossible to make a strict distinction between which elements of devotional fitness are 'secular' and which are 'religious' - a finding that strikingly supports Knoblauch's thesis.

To look at devotional fitness from the theoretical perspective of semiotics will imply an examination of the symbolic stock of these movements. Only a few of the symbols belonging to this stock have been described in section 'Towards a definition of "devotional fitness". The next step is to ask here where these symbols come from; how they have been redefined for the purpose of a 'new' semiotic system and what kinds of relations exist among those signs. In this manner, it could be possible to reproduce the semiotic code which makes the system of devotional fitness a communicative system distinct from other contemporary religious systems.

\section{References}

\section{Literature}

\section{Dumont, Louis}

1991 Individualismus. Zur Ideologie der Moderne. Frankfurt am Main: Campus.

\section{Geertz, Clifford}

2009 'Religion as a cultural system.' In: Clifford Geertz, The Interpretation of Cultures: Selected Essays. 87-125. Rev. ed. 2000, reprint. New York: Basic Books. (First published in 1973.)

\section{Griffith, Ruth Marie}

2004 Born Again Bodies: Flesh and Spirit in Amerian Christiaity. California Studies in Food and Culture 12. Berkeley, CA: University of California Press.

\section{Hofschlaeger, Stephanie}

2006 'Von der Kirchturmspitze zum Sportplatz-ein Drahtseilakt? Der DJKSportverein und die Pfarrei'. Anzeiger für die Seelsorge 6: 14-18.

\section{Keilmann-Stadler, Elisabeth}

2006 'Sportexerzitien. Die etwas andere spirituelle Erfahrung.' Anzeiger für die Seelsorge 6: 11-13.

\section{Kneer, Georg \& Armin Nassehi}

1993 Niklas Luhmanns Theorie sozialer Systeme. Eine Einführung. Uni-Taschenbücher 1751. München: Wilhelm Fink. 


\section{Knoblauch, Hubert}

2008 'Die populäre Religion und die Transformation der Gesellschaft.' Aus Politik und Zeitgeschichte. Beilage zur Wochenzeitung Das Parlament, 22.12.2008.

2009 Populäre Religion. Auf dem Weg in eine spirituelle Gesellschaft. Frankfurt am Main: Campus.

\section{Mazer, Sharon}

1994 'The Power Team: muscular Christianity and the spectacle of conversion.' The Drama Review 38 (4): 162-88.

\section{Moxter, Michael}

2010 'Evangelisches Christentum.' In: Klaus Ebeling (ed.), Orientierung Weltreligionen. 72-97. Stuttgart: Kohlhammer.

\section{Pierce, Deborah}

1960 I Prayed Myself Slim. New York, NY: Citadel.

Pilates, Joseph Hubertus \& William John Miller

2007 Return to Life through Contrology. Die originalen Pilates-Übungen. Deutsche Erst- und Faksimileausgabe. Edited by Peter Ewers. Paderborn: Ewers. (First published in 1945.)

\section{Rowe, Theresa}

2008 Shaped by Faith: 10 Secrets to Strengthening Your Body \& Soul. New York, NY: Guideposts.

\section{Schrettle, Gregor}

2006 Our Own Private Exodus: Gwen Shamblin's Dieting Religion and America's Puritan Legacy. Arbeiten zur Amerikanistik 39. Essen: Die Blaue Eule.

\section{Shedd, Charlie W.}

1957 Pray Your Weight Away. Philadelphia: Lippincott.

\section{Siemes, Bernward}

2006 'Sport und Spiritualität. Bewegendes für Körper, Geist und Seele.' Anzeiger für die Seelsorge 6: 5-8.

\section{Zimmer, Svenja}

2010 'Mögliche Einflüsse protestantischer Ethik auf Ernährung, Gesundheitsverhalten und Schlankheitsideal.' Unpublished Bachelor's thesis, Hochschule Fulda.

Internet sources

\section{Baptisten-Gemeinde Hanau}

2010 Baptisten GemeindeHanau.http://www.baptisten-hanau.de/feriensportarena. html (accessed on 13 March 2012).

\section{Christian Fitness TV}

2010 Christian Fitness. http://www.christianfitnesstv.com/ (accessed on 13 March 2012). 


\section{Christian Television Network}

2010 Christian Television Network: Spreading the Gospel. http://www.ctnonline. com/ (accessed on 13 March 2012).

\section{DJK-Sportverband}

2010 DJK Sportverband: Katholischer Bundesverband für Breiten- und Leistungssport. http://www.djk.de/ (accessed on 13 March 2012).

Evangelische Kirche in Deutschland

2010 Kirche und Sport. http://www.ekd.de/kirche-und-sport/ (accessed on 13 March 2012).

Lapka, D.

2007 'Drei-Punkte-Wurf: Klerikale Leidenschaften.' YOU! Magazin. http://www. youmagazin.com/page/show_details/44-reportagen/343-drei-punkte-wurf (accessed on 22 December 2010, no longer available online on 13 March 2012).

\section{Missionswerk Neues Leben}

2010 Neues Leben Seminar. http://www.seminar.neues-leben.de/ (accessed on 13 March 2012).

\section{Owensboro Christian Church}

2008 Owensboro Christian Recreation Ministry. http://www.owensborochristian. org/\#/rec-center (accessed on 13 March 2012).

\section{The Power Team}

2007 Todd Keen and the Power Team. http://www.thepowerteam.com/ (accessed on 13 March 2012).

Rowe, $\mathbf{T}$.

2010 Shaped By Faith. http://www.shapedbyfaith.com/ (accessed on 13 March 2012).

Schmidts, H.-G., K. Schmidt \& B. Breitmaier

2010 SRS. http://www.srsonline.de/ (accessed on 13 March 2012).

Weigh Down Ministries

2010 Weigh Down Ministries: Permanent Weigh Loss \& The Solution to All Addictions. http://www.weighdown.com/ (accessed on 13 March 2012). 